\title{
Electrical Remodeling in the Failing Heart
}

\author{
Takeshi Aiba, MD, PhD and Gordon F. Tomaselli, MD
}

\begin{abstract}
Purpose of review-We focus on the molecular and cellular basis of excitability, conduction and electrical remodeling in the heart failure with dyssynchronous LV contraction (DHF) and its restoration by cardiac resynchronization therapy (CRT) using a canine tachy-pacing heart failure (HF) model.
\end{abstract}

Recent findings-The electrophysiological hallmark of cells and tissues isolated from failing hearts is prolongation of action potential duration (APD) and conduction slowing. In human studies and a number of animal models of $\mathrm{HF}$, functional downregulation of $\mathrm{K}$ currents and alterations in depolarizing $\mathrm{Na}$ and $\mathrm{Ca}$ currents and transporters are demonstrated. Alterations in intercellular ion channels and matrix contribute to heterogeneity of APD and conduction slowing. The changes in cellular and tissue function are regionally heterogenous particularly in the DHF. Furthermore, $\beta$ adrenergic signaling and modulation of ionic currents is blunted in HF.

CRT partially reversed the DHF-induced downregulation of K current and improved Na channel gating. CRT significantly improved Ca homeostasis especially in lateral myocytes, and restored the DHF-induced blunted $\beta$-adrenergic receptor responsiveness. CRT abbreviated DHF-induced prolongation of APD in the lateral myocytes and reduced the LV regional gradient of APD, and suppressed development of EADs.

Summary-CRT partially restores DHF-induced electrophysiological remodeling, abnormal Ca homeostasis, blunted $\beta$-adrenergic responsiveness and regional heterogeneity of APD, thus may suppress ventricular arrhythmias and contribute to the mortality benefit of CRT as well as improve mechanical performance of the heart.

\section{Keywords}

Ion channels; action potential; gene expression; heart failure; remodeling

\section{Introduction}

Heart failure (HF) is highly prevalent, accounting for more than 250,000 deaths annually in the US. The incidence and prevalence has continued to increase with the aging of the US population [1]. Despite remarkable improvements in medical therapy the prognosis of patients with myocardial failure remains poor with almost $20 \%$ of patients dying within one year of initial diagnosis and greater than $80 \%$ eight-year mortality. Of the deaths in patients with HF, up to $50 \%$ are sudden and unexpected; indeed, patients with HF have 6-9 times the rate of sudden cardiac death of the general population [1].

Correspondence: Gordon F. Tomaselli, MD, Michel Mirowski MD Professor of Cardiology, Chief of Cardiology, Johns Hopkins University School of Medicine, Baltimore, MD 21205, gtomasel@jhmi.edu.

Publisher's Disclaimer: This is a PDF file of an unedited manuscript that has been accepted for publication. As a service to our customers we are providing this early version of the manuscript. The manuscript will undergo copyediting, typesetting, and review of the resulting proof before it is published in its final citable form. Please note that during the production process errors may be discovered which could affect the content, and all legal disclaimers that apply to the journal pertain. 
HF is associated with anatomic and functional remodeling of cardiac tissues in both animal models and humans, which alters cardiac electrophysiology. Indeed, abnormalities of atrial and ventricular electrophysiology in diseased human hearts have been recognized for over four decades. Remodeling of myocyte electrophysiology in HF is well described, recent data suggests that the pattern of electrical and mechanical activation may influence this remodeling.

\section{Prolongation of APD and development of EADs}

The hallmark of cells and tissues isolated from failing hearts independent of the etiology is action potential (AP) prolongation [2-8]. The AP reflects a delicate balance between the activity of several depolarizing and repolarizing ionic currents, transporters, and exchangers, which are not uniformly expressed in the ventricular wall (Figure 1). The prolongation of AP in $\mathrm{HF}$ is heterogeneous, exaggerating the physiological inhomogeneity of electrical properties in the failing heart.[3,9] The AP prolongation in HF is highly arrhythmogenic with frequent early afterdepolarizations (EADs) that are not observed in ventricular myocytes isolated from control hearts.

\section{$\mathrm{K}^{+}$current remodeling}

$\mathrm{K}^{+}$current down regulation is a regular finding in the failing heart. The detailed changes in currents and channels vary with the model of HF; however, the consistent effect is the generation of heterogeneous prolongation of APD.

\section{Transient outward $\mathrm{K}+$ current $\left(\mathrm{I}_{\mathrm{to}}\right)$}

Although expressed cardiac $\mathrm{K}^{+}$channels vary in different species. The transient outward potassium current $\left(\mathrm{I}_{\text {to }}\right)$ down regulation is the most consistent ionic current change in failing hearts $[2,4,5,7,10]$. Since, $\mathrm{I}_{\text {to }}$ is an early transient current; it may not directly affect the ventricular action potential duration (APD) in large mammalian hearts as it does in rodent ventricle. Interestingly, down-regulation of $\mathrm{I}_{\text {to }}$ in cells isolated from terminally failing human hearts is not associated with a change in its voltage dependence or kinetics [2]. The molecular mechanism of $\mathrm{I}_{\text {to }}$ down-regulation in $\mathrm{HF}$ is likely to be multifactorial. Reduced steady-state levels of Kv4 mRNA are highly correlated with functional down-regulation of $\mathrm{I}_{\text {to }}$ in human $\mathrm{HF}[5,10-13]$. In a canine model, tachycardia down regulates $\mathrm{I}_{\text {to }}$ expression, with the $\mathrm{Ca}^{2+}$ / calmodulin-dependent protein kinase II (CaMKII) and calcineurin/NFAT systems playing key $\mathrm{Ca}^{2+}$-sensing and signal-transducing roles in rate-dependent $\mathrm{I}_{\text {to }}$ control.[14]

\section{Inward rectifier $\mathrm{K}^{+}$current $\left(\mathrm{I}_{\mathrm{K} 1}\right)$}

Reduced inward $\mathrm{I}_{\mathrm{K} 1}$ density in $\mathrm{HF}$ may contribute to prolongation of APD and enhanced susceptibility to spontaneous membrane depolarizations including delayed afterdepolarizations (DADs) $[6,9,15,16]$ Changes in $\mathrm{I}_{\mathrm{K} 1}$ functional expression are more variable than $\mathrm{I}_{\text {to }}$, and controversial. Even within the same experimental model of HF induction (e.g. pacing-tachycardia), inconsistencies have been observed across species: reduced $\mathrm{I}_{\mathrm{K} 1}$ density in canine [4,9] but no change in rabbit [17]. In terminal human $\mathrm{HF}, \mathrm{I}_{\mathrm{K} 1}$ is significantly reduced at negative voltages, [2] but the underlying basis for such down-regulation appears to be post-transcriptional in light of the absence of changes in the steady-state level of Kir2.1 mRNA. [5]

The molecular basis of $\mathrm{I}_{\mathrm{K} 1}$ down regulation in $\mathrm{HF}$ remains controversial without consistent changes in the expression of Kir2 family of genes. Even the specific subunit(s) that underlie $\mathrm{I}_{\mathrm{K} 1}$ vary as function of species and cardiac chamber, although Kir2.1 and 2.2 knockout [18] and Kir2.1 dominant negative over expressing mice [19] exhibit prolonged APDs. 


\section{Delayed rectifier $\mathrm{K}$ currents $\left(\mathrm{I}_{\mathrm{Kr}}\right.$ and $\left.\mathrm{I}_{\mathrm{Ks}}\right)$}

The delayed rectifier $\mathrm{K}^{+}$currents play a prominent role in the late phase of repolarization, [20] therefore changes in either the slow $\left(\mathrm{I}_{\mathrm{Ks}}\right)$ or fast $\left(\mathrm{I}_{\mathrm{Kr}}\right)$ activating components of this current could contribute significantly to AP prolongation in HF. Reduced $\mathrm{I}_{\mathrm{K}}$ density, slower activation, and faster deactivation kinetics have been observed in hypertrophied feline ventricles.[21] Down regulation of both $\mathrm{I}_{\mathrm{Kr}}$ and $\mathrm{I}_{\mathrm{Ks}}$ have been reported in a rabbit model of rapid ventricular pacing $\mathrm{HF}$, [7] whereas $\mathrm{I}_{\mathrm{Ks}}$ but not $\mathrm{I}_{\mathrm{Kr}}$ was down regulated in all layers of the left ventricular myocardium in a canine model of same tachy-pacing HF.[9] The molecular basis for $\mathrm{I}_{\mathrm{K}}$ down regulation in HF remains uncertain. We recently measured mRNA levels of the genes encoding the $\alpha$ subunits for the rapidly (HERG) and slowly (KvLQT1) activating components of $I_{K}$ in normal and failing canine hearts and found no statistical difference [5].

\section{$\mathrm{Ca}^{2+}$ currents and $\mathrm{Ca}^{2+}$ transients}

Altered $\mathrm{Ca}^{2+}$ homeostasis underlies abnormalities in excitation-contraction coupling and arrhythmic risk in HF. Intracellular $\left[\mathrm{Ca}^{2+}\right]$ and the AP are intricately linked by a variety of $\mathrm{Ca}^{2+}$-mediated cell surface channels and transporters such as $\mathrm{I}_{\mathrm{Ca}-\mathrm{L}}, \mathrm{I}_{\mathrm{K}}, \mathrm{Ca}^{2+}$-activated $\mathrm{Cl}-$ current, and NCX. $\mathrm{I}_{\mathrm{Ca}-\mathrm{L}}$ density is unchanged or reduced in HF, the latter typically occurring in more advanced disease.[22] Remarkably in human HF baseline $\mathrm{I}_{\mathrm{Ca}-\mathrm{L}}$ density is consistently unchanged; [23] although single channel studies suggest a reduction in channel number with an increase in open probability perhaps due to altered phosphorylation or subunit composition. [24] The molecular bases of changes in the density of $\mathrm{I}_{\mathrm{Ca}-\mathrm{L}}$ are incompletely understood, subunit mRNA expression in HF is variable. [25] The complexity of the molecular Ca channel remodeling is highlighted by reports of isoform switching of both $\alpha 1 \mathrm{C}$ [26] and $\beta$ subunits in the failing heart. [27]

The amplitude of the calcium transient (CaT) and its rate of decay are reduced in intact preparations and cells isolated from failing ventricles. [28] Systematic comparisons of the CaT profile and dynamics in cells isolated from different regions of the failing heart are limited. Sarcoplasmic reticulum $\mathrm{Ca}^{2+}$-ATPase (SERCA2a), its inhibitor phospholamban (PLN) and NCX are primary mediators of $\mathrm{Ca}^{2+}$ removal from the cytoplasm. In HF, ventricular myocytes exhibit a greater reliance on NCX for removal of $\mathrm{Ca}^{2+}$ from the cytosol and an increase in NCX function,[29] which leads to defective SR $\mathrm{Ca}^{2+}$ loading.[30] Altered NCX function in HF significantly influences CaT and AP dynamics.[31] $\mathrm{SR} \mathrm{Ca}^{2+}$ release is also defective in the failing heart and is associated with altered regulation of the ryanodine receptor (RyR).[32] Hyperphosphorylation of RyR by protein kinase A [33] or CaMKII [34] may increase diastolic $\mathrm{Ca}^{2+}$ leak and generate spontaneous $\mathrm{Ca}^{2+}$ waves underlying triggered arrhythmias in HF. The role of RyR regulation and gating in altered systolic function and arrhythmic risk in $\mathrm{HF}$ remains controversial [35-37]. Recently, increased inositol 1,4,5-trisphosphate receptors(Ins $\mathrm{P}_{3} \mathrm{Rs}$ ) expression has been suggested to be a general mechanism that underlies remodeling of $\mathrm{Ca}^{2+}$ signaling during heart disease, and in particular, in triggering ventricular arrhythmia during hypertrophy.[38] On the other hand, CaMKII $\delta$ contributes to cardiac decompensation by enhancing RyR2-mediated SR $\mathrm{Ca}^{2+}$ leak and that attenuating CaMKII $\delta$ activation can limit the progression to heart failure.[39] The HF-related alterations in RyR2 function mimic the changes caused by posttranslational modification by reactive oxygen species, thus redox modification of RyR may contribute to SR $\mathrm{Ca}^{2+}$ leak in chronic HF.[40]

\section{$\mathrm{Na}^{+}$channel and late $\mathrm{I}_{\mathrm{Na}}$}

Studies of $\mathrm{I}_{\mathrm{Na}}$ in a canine infarct model of $\mathrm{HF}$ revealed a significant down regulation of the current, an acceleration of its inactivation properties, and a slowing of its recovery from inactivation in myocytes isolated from the infarct border zone.[41] Normal impulse formation and conduction depend on the fast inward $\mathrm{I}_{\mathrm{Na}}$. Also, an increase in the late component of $\mathrm{Na}$ 
current (late $\mathrm{I}_{\mathrm{Na}}$ ) can markedly prolong APD and promote polymorphic VT. Therefore, changes in $\mathrm{I}_{\mathrm{Na}}$ density and kinetics may predispose to arrhythmias either by disrupting conduction and/ or prolonging repolarization.

In a canine model of ischemic $\mathrm{HF}$, significant down-regulation of $\mathrm{I}_{\mathrm{Na}}$, acceleration of its inactivation properties, and slowing of its recovery from inactivation were observed.[41] a significant increase in the late $\mathrm{I}_{\mathrm{Na}}$ was demonstrated in human and canine HF.[42] [43] A recent study has shown that intracellular $\mathrm{Ca}^{2+} \mathrm{CaMKII}$ signaling increases late $\mathrm{I}_{\mathrm{Na}}$ by slowing inactivation kinetics and shifting steady state inactivation.[44] [45] Changes in $\mathrm{I}_{\mathrm{Na}}$ are likely to depend on the specific disease etiology, and may have profound implications for arrhythmogenesis given the relative abundance and importance of this current to wavefront propagation.

\section{Conduction and connexin remodeling in HF}

Slowed intraventricular conduction is a prominent feature of $\mathrm{HF}$ and is associated with a reduction in the density, altered distribution and post-translational modification of the major cardiac gap junction protein (connexin 43, Cx43).[46] Similar findings have been observed in hypertrophied and ischemic human ventricular myocardium, $\mathrm{Cx} 43$ is down regulated and redistributed from the intercalated disk to the entire cell border (lateralization) [47-49], a pattern observed in early cardiac development. We observed down regulation and lateralization of $\mathrm{Cx} 43$ in HF[46] that is progressive with duration of tachypacing[50] and associated with conduction slowing. The mechanism of $\mathrm{Cx} 43$ down regulation is not completely understood but may involve altered rennin-angiotensin signaling [51,52] changes in binding partners $[53,54]$ or altered membrane domain localization [55]. In the pacing tachycardia HF, Cx43 down regulation is associated with a reduction in $\mathrm{Cx} 43 \mathrm{mRNA}$.

\section{DHF and the effect of CRT on electrical remodeling}

In HF with dyssynchronous contraction (DHF), bi-ventricular pacing referred to as CRT improves symptoms and reduces mortality in subsets of patients,[56] CRT is widely applied in patients with DHF, but the electrophysiological consequences of CRT are not well understood.

\section{Clinical Effects of CRT}

Is CRT pro-arrhythmic or anti-arrhythmic? Soon after starting bi-ventricular pacing, QT prolongation and development of Torsades de pointes, the arrhythmia characteristic of the long QT syndrome, has been reported [57]. LV epicardial pacing further increased QTc and JTc intervals compared to $\mathrm{Bi}-\mathrm{V}$ pacing.[58] In an acute study using a canine wedge preparation, reversal of activation by the epicardial pacing compared to the endocardial pacing increased QT, JT interval and transmural dispersion of repolarization, creating the substrate for TdP under LQT condition.[59] In patients with advanced HF and a prolonged QRS interval, CRT decreases the combined risk of death from any cause or first hospitalization and, when combined with an ICD, significantly reduces mortality.[60] On the other hand, in patients treated with CRT defibrillators, ventricular arrhythmias were reduced during the initial 12 months after implant.[61,62]

\section{CRT and regional effects on APs and ionic currents}

AP prolongation in DHF is most prominent in cells isolated from the late-activated lateral LV wall. CRT significantly shortens the AP in lateral myocytes and reduces the LV regional heterogeneity in APD (Figure 2).[12] AP prolongation in DHF is highly arrhythmogenic with frequent early afterdepolarizations (EADs) that were not observed in myocytes isolated from 
control hearts. CRT dramatically reduces the frequency of EADs in cells isolated from both the anterior and lateral LV.

The mechanisms of regional AP remodeling in the DHF and CRT are controversial. At the molecular level, tumor necrosis factor- $\alpha$ (TNF- $\alpha$ ) and CaMKII were increased in DHF prominently in the lateral wall and these differences were absent in CRT.[63] TNF- $\alpha$ decreases $\mathrm{I}_{\text {to }}$ and prolongs the APD in rat ventricular myocytes.[64] Recently, Xie et al. suggested an increased oxidative stress in HF induced CaMKII activation and triggers of ventricular arrhythmias. [65] CaMKII influences $\mathrm{Ca}^{2+}$ current, SR function,[66,67] and increases persistent $\mathrm{Na}^{+}$current $[44,45]$ resulting in prolongation of APD.[68] It is possible and indeed likely, that other regional alterations in $\mathrm{Ca}^{2+}$ handling or increased persistent $\mathrm{Na}^{+}$current contribute to regional differences in the APD and AP profile in DHF, and the regionallyspecific effects of bi-ventricular pacing on this phenotype.

$\mathrm{K}^{+}$current changes associated with CRT are variable. The down regulation of $\mathrm{I}_{\mathrm{to}}$ is regionally uniform in the left ventricle in DHF and is unique among regulated $\mathrm{K}^{+}$currents in $\mathrm{HF}$ in that it is not reversed by CRT. In parallel, Kv4.3 and KChIP2 mRNA and protein expression are down regulated in DHF without restoration by CRT.[12] CRT even in the setting of continued $\mathrm{HF}$ partially restores $\mathrm{I}_{\mathrm{K} 1}$ density and decreases membrane resistance and in the setting of improved $\mathrm{Ca}^{2+}$ handling in CRT may reduce the frequency of arrhythmogenic DADs. Kir2.1 mRNA and protein levels are partially restored by CRT in the canine model; suggesting that different mechanisms of regulation of current are operative in some animal models and human HF. CRT partially restores DHF-induced downregulation of $\mathrm{I}_{\mathrm{K}}$ density in both anterior and lateral LV myocytes without a significant change in mRNA or protein levels of KvLQT1 or minK compared with DHF, whereas ERG mRNA level was restored by CRT in either the anterior or lateral LV wall.[12]

\section{CRT restores Ca current and handling}

In DHF there are intraventricular regional changes in $\mathrm{I}_{\mathrm{Ca}-\mathrm{L}}$ that are partially restored by CRT [12]. DHF produced a reduction peak $\mathrm{I}_{\mathrm{Ca}-\mathrm{L}}$ density and slowed current decay in myocytes isolated from the late-activated lateral $\mathrm{LV}$ wall. In contrast, peak $\mathrm{I}_{\mathrm{Ca}-\mathrm{L}}$ density in anterior myocytes was increased compared with non-failing controls, thus DHF produced regional heterogeneity of $\mathrm{Ca}^{2+}$ current density and kinetics. CRT restored the peak current density but did not alter the $\mathrm{I}_{\mathrm{Ca}-\mathrm{L}}$ decay in the lateral cells, eliminating the anterior-lateral $\mathrm{I}_{\mathrm{Ca}-\mathrm{L}}$ density gradient. Neither DHF nor CRT exhibit consistent changes in $\mathrm{Ca}^{2+}$ channel subunit mRNA or protein levels.

In canine pacing DHF, CaT amplitudes are depressed and kinetics slowed particularly in cells isolated from the late-activated lateral LV myocardium and partially restored by CRT (Figure 2)[12]. In DHF, mRNA and protein levels of SERCA2a, PLN and RyR2 were down regulated and NCX up regulated without a change in CRT. There were also no regional differences in mRNA and protein expression in any of these mediators of $\mathrm{Ca}^{2+}$ handling in DHF and CRT, suggesting that the global and regional differences of $\mathrm{Ca}^{2+}$ handling function in DHF and its restoration by CRT are post translational.

The mechanisms underlying the differences in regional remodeling of $\mathrm{K}^{+}$currents and $\mathrm{Ca}^{2+}$ handling in DHF remain obscure. Plotnikov et al. reported that cardiac dyssynchrony by left ventricular pacing (120-150 bpm for 3 weeks) produced a slower decay of $\mathrm{I}_{\mathrm{Ca}}$ inactivation [69] consistent with our results. Moreover, this phenomenon was suppressed by a $\beta$-adrenergic blockade. These findings suggest that DHF-induced changes of $\mathrm{I}_{\mathrm{Ca}}$ inactivation kinetics might be mediated by regionally heterogeneous $\beta$-adrenergic receptor stimulation. Furthermore, the $\mathrm{Ca}^{2+}$-handling proteins are functionally regulated by phosphorylation, prominently by key 
intracellular enzymes protein kinase A and CaMKII, $[66,67,70]$ and a variety of phosphatases which may be regionally regulated.[63]

Reduced $\beta$-adrenergic receptor ( $\beta$-AR) function is a key feature of HF. CRT restores the DHFinduced baseline reduction of $\mathrm{I}_{\mathrm{Ca}, \mathrm{L}}$ and the blunted response to $\beta$-adrenergic ( $\left.\beta 1>>\beta 2\right)$ receptor stimulation. Moreover, $\mathrm{CRT}$ improves baseline $\mathrm{Ca}^{2+}$ handling and its adrenergic responsiveness, which may contribute to improvement in contractility and altered arrhythmia susceptibility. [71] And, these electrophysiological data is consistent to our previous molecular results that CRT increased $\beta 1 / \beta 2-\mathrm{AR}$ ratio. [72]

\section{Gene Expression changes by CRT}

We have described regional changes in signaling and protein expression in DHF, notably in stress-response kinases and cytokines with enhanced levels in the late-activated, lateral wall $[46,63,73]$. In some instances CRT can reverse these changes and produce salutary effects on overall LV function [63]. In order to better understand the breadth of signaling changes we have studied transcriptomic changes in DHF and CRT.[74] In these studies we demonstrated that genes in mitochondrial energetic pathways are similarly over represented in the lists of down regulated genes in the failing LV. In contrast, genes localized in nucleus and related to transcriptional regulation are over represented in the genes up regulated in failing LV.

In a microarray study comparing intraventricular changes in gene expression in DHF and CRT, we found that dyssynchrony-induced changes in gene expression were more pronounced in the anterior compared with the lateral LV. The genes that exhibited regional heterogeneity with dyssynchrony are involved in critical cellular processes such as metabolic pathways, extracellular matrix remodeling, and myocardial stress responses. Remarkably, dyssynchronyinduced regional expression changes were reversed to levels in normal hearts by CRT, with prominent reversal of dysregulation of expression of transcripts with metabolic and cell signaling function [75].

\section{Conclusions}

Electrophysiological remodeling of the failing heart involves changes in both active membrane properties of heart cells and network attributes of the myocardium. The pattern of electrical activation and mechanical contraction impact the cellular and tissue physiology and all seem to exaggerate the normal heterogeneity of electrophysiological properties of the heart when it is failing. The remodeling poses unique and complex challenges to the treatment of arrhythmias in the failing heart. Studies of antiarrhythmic therapy have targeted ion channels and the cardiac AP as well as changes in the cardiac interstitium with variable success. CRT alters electrical activation of the failing heart that exhibits intraventricular conduction delays and resynchronizes mechanical contraction. CRT undoubtedly benefits some patients, improving symptoms of HF and reduces sudden death when implemented with defibrillator therapy. The reversal of the exaggerated electrophysiological heterogeneity of the failing heart would suggest that CRT is antiarrhythmic, however this has yet to be demonstrated clinically.

\section{Acknowledgments}

The authors gratefully acknowledge support from the NIH NHLBI (PO1 HL077180 and RO1 HL072488).

\section{References and recommended reading}

1. Heart Disease and Stroke Statistics - 2003 Update. Heart and Stroke Facts; American Heart Association; Dallas, Texas. 2002. Edited by 
2. Beuckelmann DJ, Nabauer M, Erdmann E. Alterations of K+ currents in isolated human ventricular myocytes from patients with terminal heart failure. Circ Res 1993;73:379-385. [PubMed: 8330380]

3. Akar FG, Rosenbaum DS. Transmural electrophysiological heterogeneities underlying arrhythmogenesis in heart failure. Circ Res 2003;93:638-645. [PubMed: 12933704]

4. Kaab S, Nuss HB, Chiamvimonvat N, O'Rourke B, Pak PH, Kass DA, Marban E, Tomaselli GF. Ionic mechanism of action potential prolongation in ventricular myocytes from dogs with pacing-induced heart failure. Circ Res 1996;78:262-273. [PubMed: 8575070]

5. Kaab S, Dixon J, Duc J, Ashen D, Nabauer M, Beuckelmann DJ, Steinbeck G, McKinnon D, Tomaselli GF. Molecular basis of transient outward potassium current downregulation in human heart failure: a decrease in Kv4.3 mRNA correlates with a reduction in current density. Circulation 1998;98:13831393. [PubMed: 9760292]

6. Rose J, Armoundas AA, Tian Y, DiSilvestre D, Burysek M, Halperin V, O'Rourke B, Kass DA, Marban E, Tomaselli GF. Molecular correlates of altered expression of potassium currents in failing rabbit myocardium. Am J Physiol Heart Circ Physiol 2005;288:H2077-H2087. [PubMed: 15637125]

7. Tsuji Y, Zicha S, Qi XY, Kodama I, Nattel S. Potassium channel subunit remodeling in rabbits exposed to long-term bradycardia or tachycardia: discrete arrhythmogenic consequences related to differential delayed-rectifier changes. Circulation 2006;113:345-355. [PubMed: 16432066]

8. Nattel S, Maguy A, Le Bouter S, Yeh YH. Arrhythmogenic ion-channel remodeling in the heart: heart failure, myocardial infarction, and atrial fibrillation. Physiol Rev 2007;87:425-456. [PubMed: 17429037]

9. Li GR, Lau CP, Ducharme A, Tardif JC, Nattel S. Transmural action potential and ionic current remodeling in ventricles of failing canine hearts. Am J Physiol Heart Circ Physiol 2002;283:H1031H1041. [PubMed: 12181133]

10. Nabauer M, Beuckelmann DJ, Erdmann E. Characteristics of transient outward current in human ventricular myocytes from patients with terminal heart failure. Circ Res 1993;73:386-394. [PubMed: 8330381]

11. Zicha S, Xiao L, Stafford S, Cha TJ, Han W, Varro A, Nattel S. Transmural expression of transient outward potassium current subunits in normal and failing canine and human hearts. J Physiol 2004;561:735-748. [PubMed: 15498806]

12. Aiba T, Hesketh GG, Barth AS, Liu T, Daya S, Chakir K, Dimaano VL, Abraham TP, O'Rourke B, Akar FG, et al. Electrophysiological consequences of dyssynchronous heart failure and its restoration by resynchronization therapy. Circulation 2009;119:1220-1230. [PubMed: 19237662] - A detailed study of the changes in ionic currents and $\mathrm{Ca} 2+$ handling in a canine model of cardiac resynchronization.

13. Akar FG, Wu RC, Juang GJ, Tian Y, Burysek M, Disilvestre D, Xiong W, Armoundas AA, Tomaselli GF. Molecular mechanisms underlying K+ current downregulation in canine tachycardia-induced heart failure. Am J Physiol Heart Circ Physiol 2005;288:H2887-H2896. [PubMed: 15681701]

14. Xiao L, Coutu P, Villeneuve LR, Tadevosyan A, Maguy A, Le Bouter S, Allen BG, Nattel S. Mechanisms Underlying Rate-Dependent Remodeling of Transient Outward Potassium Current in Canine Ventricular Myocytes. Circ Res 2008;103:733-742. [PubMed: 18723449] - Describes the mechanistic role of $\mathrm{Ca} 2+/ \mathrm{CaM} / \mathrm{CaMKII}$ and calcineurin/NFAT systems in the tachycardia HFinduced down regulation of Ito

15. Nuss HB, Kaab S, Kass DA, Tomaselli GF, Marban E. Cellular basis of ventricular arrhythmias and abnormal automaticity in heart failure. Am J Physiol 1999;277:H80-H91. [PubMed: 10409185]

16. Pogwizd SM, Schlotthauer K, Li L, Yuan W, Bers DM. Arrhythmogenesis and contractile dysfunction in heart failure: Roles of sodium-calcium exchange, inward rectifier potassium current, and residual beta-adrenergic responsiveness. Circ Res 2001;88:1159-1167. [PubMed: 11397782]

17. Rozanski GJ, Xu Z, Whitney RT, Murakami H, Zucker IH. Electrophysiology of rabbit ventricular myocytes following sustained rapid ventricular pacing. J Mol Cell Cardiol 1997;29:721-732. [PubMed: 9140829]

18. Zaritsky JJ, Eckman DM, Wellman GC, Nelson MT, Schwarz TL. Targeted disruption of Kir2.1 and Kir2.2 genes reveals the essential role of the inwardly rectifying $\mathrm{K}(+)$ current in $\mathrm{K}(+)$-mediated vasodilation. Circ Res 2000;87:160-166. [PubMed: 10904001] 
19. McLerie M, Lopatin AN. Dominant-negative suppression of $\mathrm{I}(\mathrm{K} 1)$ in the mouse heart leads to altered cardiac excitability. J Mol Cell Cardiol 2003;35:367-378. [PubMed: 12689816]

20. Liu DW, Antzelevitch C. Characteristics of the delayed rectifier current (IKr and IKs) in canine ventricular epicardial, midmyocardial, and endocardial myocytes. A weaker IKs contributes to the longer action potential of the M cell. Circ Res 1995;76:351-365. [PubMed: 7859382]

21. Furukawa T, Bassett AL, Furukawa N, Kimura S, Myerburg RJ. The ionic mechanism of reperfusioninduced early afterdepolarizations in feline left ventricular hypertrophy. J Clin Invest 1993;91:15211531. [PubMed: 8386189]

22. Pitt GS, Dun W, Boyden PA. Remodeled cardiac calcium channels. J Mol Cell Cardiol 2006;41:373388. [PubMed: 16901502]

23. Chen X, Piacentino V 3rd, Furukawa S, Goldman B, Margulies KB, Houser SR. L-type Ca2+ channel density and regulation are altered in failing human ventricular myocytes and recover after support with mechanical assist devices. Circ Res 2002;91:517-524. [PubMed: 12242270]

24. Schroder F, Handrock R, Beuckelmann DJ, Hirt S, Hullin R, Priebe L, Schwinger RH, Weil J, Herzig S. Increased availability and open probability of single L-type calcium channels from failing compared with nonfailing human ventricle. Circulation 1998;98:969-976. [PubMed: 9737516]

25. Takahashi T, Allen PD, Lacro RV, Marks AR, Dennis AR, Schoen FJ, Grossman W, Marsh JD, Izumo $\mathrm{S}$. Expression of dihydropyridine receptor $(\mathrm{Ca} 2+\mathrm{channel})$ and calsequestrin genes in the myocardium of patients with end-stage heart failure. J Clin Invest 1992;90:927-935. [PubMed: 1326001]

26. Yang Y, Chen X, Margulies K, Jeevanandam V, Pollack P, Bailey BA, Houser SR. L-type Ca2+ channel alpha 1c subunit isoform switching in failing human ventricular myocardium. J Mol Cell Cardiol 2000;32:973-984. [PubMed: 10888251]

27. Hullin R, Khan IF, Wirtz S, Mohacsi P, Varadi G, Schwartz A, Herzig S. Cardiac L-type calcium channel beta-subunits expressed in human heart have differential effects on single channel characteristics. J Biol Chem 2003;278:21623-21630. [PubMed: 12606548]

28. O'Rourke B, Kass DA, Tomaselli GF, Kaab S, Tunin R, Marban E. Mechanisms of altered excitationcontraction coupling in canine tachycardia-induced heart failure, I: experimental studies. Circ Res 1999;84:562-570. [PubMed: 10082478]

29. Hobai IA, O'Rourke B. Enhanced $\mathrm{Ca}(2+)$-activated $\mathrm{Na}(+)-\mathrm{Ca}(2+)$ exchange activity in canine pacinginduced heart failure. Circ Res 2000;87:690-698. [PubMed: 11029405]

30. Hobai IA, O'Rourke B. Decreased sarcoplasmic reticulum calcium content is responsible for defective excitation-contraction coupling in canine heart failure. Circulation 2001;103:1577-1584. [PubMed: 11257088]

31. Armoundas AA, Hobai IA, Tomaselli GF, Winslow RL, O'Rourke B. Role of sodium-calcium exchanger in modulating the action potential of ventricular myocytes from normal and failing hearts. Circ Res 2003;93:46-53. [PubMed: 12805237]

32. Reiken S, Gaburjakova M, Guatimosim S, Gomez AM, D'Armiento J, Burkhoff D, Wang J, Vassort G, Lederer WJ, Marks AR. Protein kinase A phosphorylation of the cardiac calcium release channel (ryanodine receptor) in normal and failing hearts. Role of phosphatases and response to isoproterenol. J Biol Chem 2003;278:444-453. [PubMed: 12401811]

33. Marx SO, Reiken S, Hisamatsu Y, Jayaraman T, Burkhoff D, Rosemblit N, Marks AR. PKA phosphorylation dissociates FKBP12.6 from the calcium release channel (ryanodine receptor): defective regulation in failing hearts. Cell 2000;101:365-376. [PubMed: 10830164]

34. Curran J, Hinton MJ, Rios E, Bers DM, Shannon TR. Beta-adrenergic enhancement of sarcoplasmic reticulum calcium leak in cardiac myocytes is mediated by calcium/calmodulin-dependent protein kinase. Circ Res 2007;100:391-398. [PubMed: 17234966]

35. Jiang MT, Lokuta AJ, Farrell EF, Wolff MR, Haworth RA, Valdivia HH. Abnormal Ca2+ release, but normal ryanodine receptors, in canine and human heart failure. Circ Res 2002;91:1015-1022. [PubMed: 12456487]

36. Xiao B, Jiang MT, Zhao M, Yang D, Sutherland C, Lai FA, Walsh MP, Warltier DC, Cheng H, Chen SR. Characterization of a novel PKA phosphorylation site, serine-2030, reveals no PKA hyperphosphorylation of the cardiac ryanodine receptor in canine heart failure. Circ Res 2005;96:847-855. [PubMed: 15790957] 
37. MacDonnell SM, Garcia-Rivas G, Scherman JA, Kubo H, Chen X, Valdivia H, Houser SR. Adrenergic regulation of cardiac contractility does not involve phosphorylation of the cardiac ryanodine receptor at serine 2808. Circ Res 2008;102:e65-e72. [PubMed: 18388322]

38. Harzheim D, Movassagh M, Foo RS, Ritter O, Tashfeen A, Conway SJ, Bootman MD, Roderick HL. Increased InsP3Rs in the junctional sarcoplasmic reticulum augment $\mathrm{Ca} 2+$ transients and arrhythmias associated with cardiac hypertrophy. Proc Natl Acad Sci U S A 2009;106:11406-11411. [PubMed: 19549843]

39. Ling H, Zhang T, Pereira L, Means CK, Cheng H, Gu Y, Dalton ND, Peterson KL, Chen J, Bers D, et al. Requirement for $\mathrm{Ca} 2+/$ calmodulin-dependent kinase II in the transition from pressure overloadinduced cardiac hypertrophy to heart failure in mice. J Clin Invest 2009;119:1230-1240. [PubMed: 19381018]

40. Terentyev D, Gyorke I, Belevych AE, Terentyeva R, Sridhar A, Nishijima Y, de Blanco EC, Khanna $\mathrm{S}$, Sen CK, Cardounel AJ, et al. Redox modification of ryanodine receptors contributes to sarcoplasmic reticulum Ca2+ leak in chronic heart failure. Circ Res 2008;103:1466-1472. [PubMed: 19008475] - A study demonstrating the effect of oxidant stress on Ca2+ handling in a canine model of HF.

41. Pu J, Boyden PA. Alterations of $\mathrm{Na}+$ currents in myocytes from epicardial border zone of the infarcted heart. A possible ionic mechanism for reduced excitability and postrepolarization refractoriness. Circ Res 1997;81:110-119. [PubMed: 9201034]

42. Undrovinas AI, Maltsev VA, Sabbah HN. Repolarization abnormalities in cardiomyocytes of dogs with chronic heart failure: role of sustained inward current. Cell Mol Life Sci 1999;55:494-505. [PubMed: 10228563]

43. Valdivia CR, Chu WW, Pu J, Foell JD, Haworth RA, Wolff MR, Kamp TJ, Makielski JC. Increased late sodium current in myocytes from a canine heart failure model and from failing human heart. $J$ Mol Cell Cardiol 2005;38:475-483. [PubMed: 15733907]

44. Maltsev VA, Reznikov V, Undrovinas NA, Sabbah HN, Undrovinas A. Modulation of late sodium current by $\mathrm{Ca} 2+$, calmodulin, and CaMKII in normal and failing dog cardiomyocytes: similarities and differences. Am J Physiol Heart Circ Physiol 2008;294:H1597-H1608. [PubMed: 18203851] • In cells isolated from normal hearts and a chronic canine model of $\mathrm{HF}, \mathrm{Ca}^{2+} / \mathrm{CaM} / \mathrm{CamKII}$ signaling slows inactivation of $\mathrm{Na}^{+}$currents.

45. Wagner S, Dybkova N, Rasenack EC, Jacobshagen C, Fabritz L, Kirchhof P, Maier SK, Zhang T, Hasenfuss G, Brown JH, et al. Ca2+/calmodulin-dependent protein kinase II regulates cardiac $\mathrm{Na}+$ channels. J Clin Invest 2006;116:3127-3138. [PubMed: 17124532]

46. Akar FG, Spragg DD, Tunin RS, Kass DA, Tomaselli GF. Mechanisms underlying conduction slowing and arrhythmogenesis in nonischemic dilated cardiomyopathy. Circ Res 2004;95:717-725. [PubMed: 15345654]

47. Peters NS, Green CR, Poole-Wilson PA, Severs NJ. Reduced content of connexin43 gap junctions in ventricular myocardium from hypertrophied and ischemic human hearts. Circulation 1993;88:864875. [PubMed: 8394786]

48. Kalcheva N, Qu J, Sandeep N, Garcia L, Zhang J, Wang Z, Lampe PD, Suadicani SO, Spray DC, Fishman GI. Gap junction remodeling and cardiac arrhythmogenesis in a murine model of oculodentodigital dysplasia. Proc Natl Acad Sci U S A 2007;104:20512-20516. [PubMed: 18077386]

49. Kostin S, Dammer S, Hein S, Klovekorn WP, Bauer EP, Schaper J. Connexin 43 expression and distribution in compensated and decompensated cardiac hypertrophy in patients with aortic stenosis. Cardiovasc Res 2004;62:426-436. [PubMed: 15094362]

50. Akar FG, Nass RD, Hahn S, Cingolani E, Shah M, Hesketh GG, DiSilvestre D, Tunin RS, Kass DA, Tomaselli GF. Dynamic changes in conduction velocity and gap junction properties during development of pacing-induced heart failure. Am J Physiol Heart Circ Physiol 2007;293:H1223H1230. [PubMed: 17434978]

51. Emdad L, Uzzaman M, Takagishi Y, Honjo H, Uchida T, Severs NJ, Kodama I, Murata Y. Gap junction remodeling in hypertrophied left ventricles of aortic-banded rats: prevention by angiotensin II type 1 receptor blockade. J Mol Cell Cardiol 2001;33:219-231. [PubMed: 11162128]

52. Yoshioka J, Prince RN, Huang H, Perkins SB, Cruz FU, MacGillivray C, Lauffenburger DA, Lee RT. Cardiomyocyte hypertrophy and degradation of connexin 43 through spatially restricted 
autocrine/paracrine heparin-binding EGF. Proc Natl Acad Sci U S A 2005;102:10622-10627. [PubMed: 16020536]

53. Barker RJ, Price RL, Gourdie RG. Increased association of ZO-1 with connexin43 during remodeling of cardiac gap junctions. Circ Res 2002;90:317-324. [PubMed: 11861421]

54. Shaw RM, Fay AJ, Puthenveedu MA, von Zastrow M, Jan YN, Jan LY. Microtubule plus-end-tracking proteins target gap junctions directly from the cell interior to adherens junctions. Cell 2007;128:547560. [PubMed: 17289573]

55. Hesketh GG, Shah MH, Kass DA, Van Eyk JE, Tomaselli GF. Gap Junction Internalization and Autophagic Degradation in the Failing Heart. Circulation 2008;118:340.

56. Cleland JG, Daubert JC, Erdmann E, Freemantle N, Gras D, Kappenberger L, Tavazzi L. The effect of cardiac resynchronization on morbidity and mortality in heart failure. N Engl J Med 2005;352:1539-1549. [PubMed: 15753115]

57. Medina-Ravell VA, Lankipalli RS, Yan GX, Antzelevitch C, Medina-Malpica NA, Medina-Malpica OA, Droogan C, Kowey PR. Effect of epicardial or biventricular pacing to prolong QT interval and increase transmural dispersion of repolarization: does resynchronization therapy pose a risk for patients predisposed to long QT or torsade de pointes? Circulation 2003;107:740-746. [PubMed: 12578878]

58. Harada M, Osaka T, Yokoyama E, Takemoto Y, Ito A, Kodama I. Biventricular pacing has an advantage over left ventricular epicardial pacing alone to minimize proarrhythmic perturbation of repolarization. J Cardiovasc Electrophysiol 2006;17:151-156. [PubMed: 16533252]

59. Fish JM, Di Diego JM, Nesterenko V, Antzelevitch C. Epicardial activation of left ventricular wall prolongs QT interval and transmural dispersion of repolarization: implications for biventricular pacing. Circulation 2004;109:2136-2142. [PubMed: 15078801]

60. Bristow MR, Saxon LA, Boehmer J, Krueger S, Kass DA, De Marco T, Carson P, DiCarlo L, DeMets D, White BG, et al. Cardiac-resynchronization therapy with or without an implantable defibrillator in advanced chronic heart failure. N Engl J Med 2004;350:2140-2150. [PubMed: 15152059]

61. Di Biase L, Gasparini M, Lunati M, Santini M, Landolina M, Boriani G, Curnis A, Bocchiardo M, Vincenti A, Denaro A, et al. Antiarrhythmic effect of reverse ventricular remodeling induced by cardiac resynchronization therapy: the InSync ICD (Implantable Cardioverter-Defibrillator) Italian Registry. J Am Coll Cardiol 2008;52:1442-1449. [PubMed: 19017510] • In a registry of patients with CRT-D devices, a reduction in the number of ventricular arrhythmic events was observed at 12 months.

62. Markowitz SM, Lewen JM, Wiggenhorn CJ, Abraham WT, Stein KM, Iwai S, Lerman BB. Relationship of reverse anatomical remodeling and ventricular arrhythmias after cardiac resynchronization. J Cardiovasc Electrophysiol 2009;20:293-298. [PubMed: 19175852]

63. Chakir K, Daya SK, Tunin RS, Helm RH, Byrne MJ, Dimaano VL, Lardo AC, Abraham TP, Tomaselli GF, Kass DA. Reversal of global apoptosis and regional stress kinase activation by cardiac resynchronization. Circulation 2008;117:1369-1377. [PubMed: 18316490] • CRT reverses regional stress kinase and CaMKII activity in canine model of HF with dyssynchrony

64. Fernandez-Velasco M, Ruiz-Hurtado G, Hurtado O, Moro MA, Delgado C. TNF-alpha downregulates transient outward potassium current in rat ventricular myocytes through iNOS overexpression and oxidant species generation. Am J Physiol Heart Circ Physiol 2007;293:H238-H245. [PubMed: 17337591]

65. Xie LH, Chen F, Karagueuzian HS, Weiss JN. Oxidative-stress-induced afterdepolarizations and calmodulin kinase II signaling. Circ Res 2009;104:79-86. [PubMed: 19038865] - Increased oxidative stress in HF may induce CaMKII activation and triggers of ventricular arrhythmias.

66. Kohlhaas M, Zhang T, Seidler T, Zibrova D, Dybkova N, Steen A, Wagner S, Chen L, Brown JH, Bers DM, et al. Increased sarcoplasmic reticulum calcium leak but unaltered contractility by acute CaMKII overexpression in isolated rabbit cardiac myocytes. Circ Res 2006;98:235-244. [PubMed: 16373600]

67. Maier LS, Zhang T, Chen L, DeSantiago J, Brown JH, Bers DM. Transgenic CaMKIIdeltaC overexpression uniquely alters cardiac myocyte $\mathrm{Ca} 2+$ handling: reduced $\mathrm{SR} \mathrm{Ca} 2+$ load and activated SR Ca2+ release. Circ Res 2003;92:904-911. [PubMed: 12676813] 
68. Wu Y, Temple J, Zhang R, Dzhura I, Zhang W, Trimble R, Roden DM, Passier R, Olson EN, Colbran RJ, et al. Calmodulin kinase II and arrhythmias in a mouse model of cardiac hypertrophy. Circulation 2002;106:1288-1293. [PubMed: 12208807]

69. Plotnikov AN, Yu H, Geller JC, Gainullin RZ, Chandra P, Patberg KW, Friezema S, Danilo P Jr. Cohen IS, Feinmark SJ, et al. Role of L-type calcium channels in pacing-induced short-term and long-term cardiac memory in canine heart. Circulation 2003;107:2844-2849. [PubMed: 12756152]

70. Ai X, Curran JW, Shannon TR, Bers DM, Pogwizd SM. Ca2+/calmodulin-dependent protein kinase modulates cardiac ryanodine receptor phosphorylation and sarcoplasmic reticulum $\mathrm{Ca} 2+$ leak in heart failure. Circ Res 2005;97:1314-1322. [PubMed: 16269653]

71. Aiba T, Barth AS, Liu T, Chakir K, Hesketh GG, Dimaano VL, Abraham TP, O'Rourke B, Akar FG, Kass DA, et al. Cardiac Resynchronization Therapy Restores • Adrenergic Reserve of Ca2+ Homeostasis in a Canine Model of Dyssynchronous Heart Failure. Circulation 2008;118:523-524.

72. Chakir K, Daya SK, Aiba T, Tunin RS, Dimaano VL, Abraham TP, Jacques K, Lai EW, Pacak K, Zhu WZ, et al. Mechanisms of enhanced \{beta\}-adrenergic reserve from cardiac resynchronization therapy. Circulation 2009;119:1231-1240. [PubMed: 19237665] • Improvement in beta adrenergic signaling in an animal model of heart failure with dyssynchronous contraction treated with CRT.

73. Spragg DD, Akar FG, Helm RH, Tunin RS, Tomaselli GF, Kass DA. Abnormal conduction and repolarization in late-activated myocardium of dyssynchronously contracting hearts. Cardiovasc Res 2005;67:77-86. [PubMed: 15885674]

74. Gao Z, Barth AS, DiSilvestre D, Akar FG, Tian Y, Tanskanen A, Kass DA, Winslow RL, Tomaselli GF. Key pathways associated with heart failure development revealed by gene networks correlated with cardiac remodeling. Physiol Genomics 2008;35:222-230. [PubMed: 18780759] • In a canine model of tachycardia pacing heart failure, down regulation in genes in metabolic pathways particularly oxidative phosphorylation is observed with up regulation of genes in a number of cell signaling pathways.

75. Barth AS, Aiba T, Halperin V, DiSilvestre D, Chakir K, Colantuoni C, Tunin RS, Dimaano VL, YU W, Abraham TP, et al. Cardiac Resynchronization Therapy Corrects Dyssynchrony-induced Regional Gene Expression Changes on a Genomic Level. Circulation Cardiovasc Genetics. 2009 in press. $\bullet$ CRT reverses the regional heterogeneity of gene expression induced by heart failure with dyssynchronous mechanical contraction.

Curr Opin Cardiol. Author manuscript; available in PMC 2011 January 1. 


\section{Ionic Basis for Altered Ventricular AP by Heart Failure}
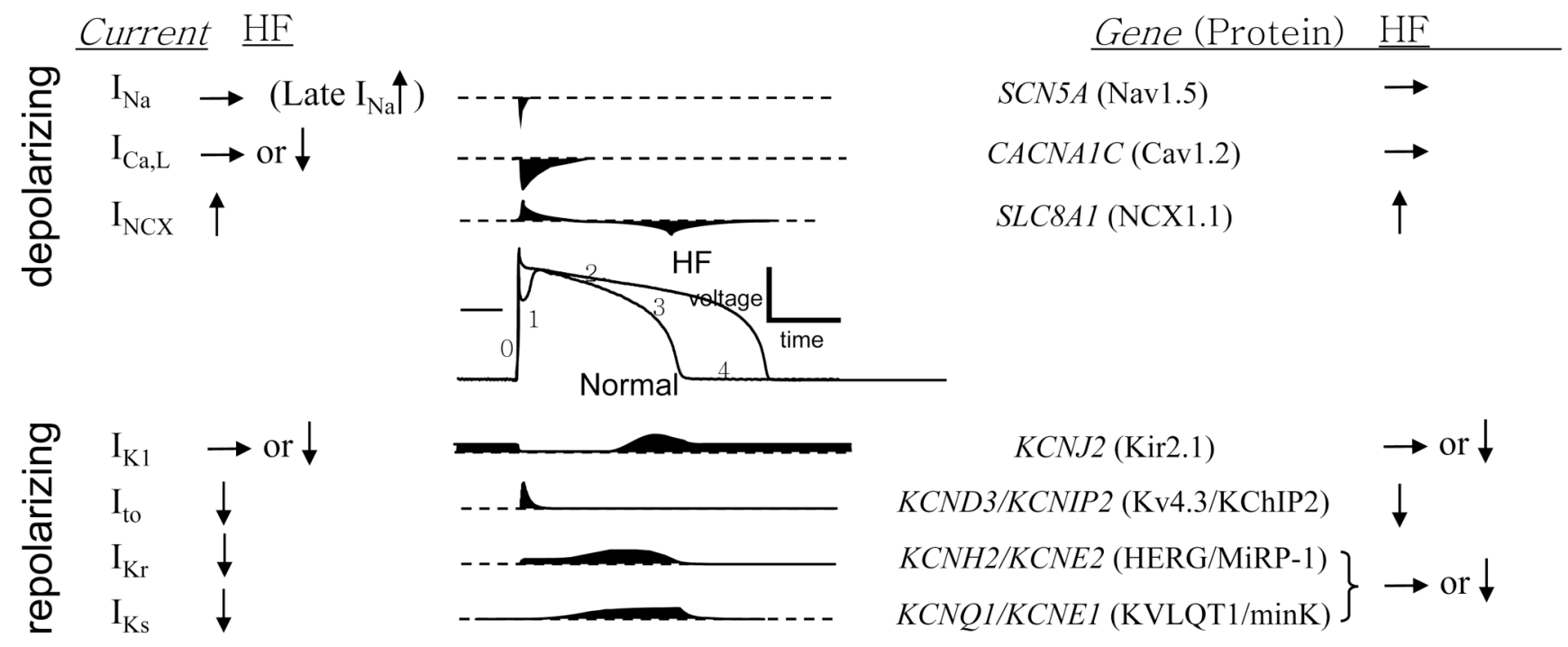

Figure 1.

Schematic of inward and outward ionic currents, pumps, and exchangers, which inscribe the mammalian ventricular action potential. A schematic of the time course of each current is shown (left), and the gene product that underlies the current is indicated (right). 


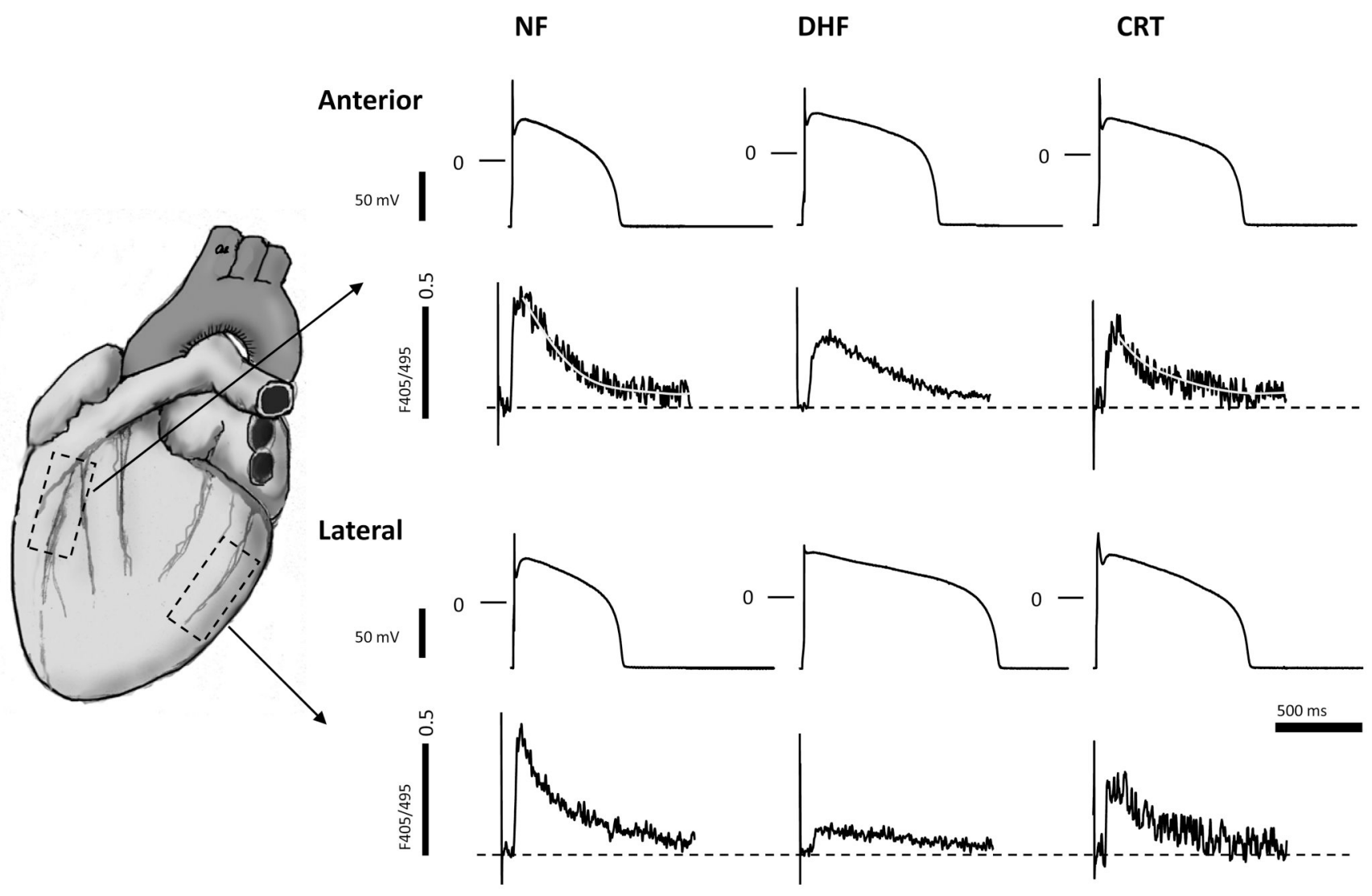

Figure 2.

Regional heterogeneity of action potential (AP) and Ca transient (CaT) in DHF and its restoration by CRT.

CRT abbreviates DHF-induced prolongation of APD and restores amplitude and decay of CaT in the lateral cells, thus reduced regional heterogeneity of repolarization and $\mathrm{Ca}$ handling. 